\title{
Impact of dynamic capacities on the performance of food and beverage enterprises in Lagos, Nigeria
}

\author{
Lu Lin Zhou ${ }^{1 *}$, James Onuche Ayegba ${ }^{1}$ Emmanuel Onu Ayegba², Peace Maina Ayegba ${ }^{3}$ and Zhang Xin Jie
}

\author{
* Correspondence: zll62@126.com \\ ${ }^{1}$ School of Management Science \\ and Engineering, Jiangsu University, \\ Jiangsu 212013, China \\ Full list of author information is \\ available at the end of the article
}

\begin{abstract}
This study examined the impact of dynamic capacities on the performance of food and beverage enterprises in Lagos, Nigeria. The following sub-variables (strategic decision-making capacity, product innovation capacity, strategic flexibility, competitive intensity, technological turbulence, and technological capability) were employed to represent the variable of dynamic capacity. Also, the following subvariables (sales growth, enterprise survival, enterprise efficiency, and competitive advantage) were employed to represent the variable of enterprise performance. Primary data was used to achieve descriptive and inferential statistics, and the statistics is estimated by the PLS-SEM method which was calibrated on Lisrel 8.70 software. This study found that product innovation, competitive intensity and technological turbulence, technological capability and competitive intensity, and strategic flexibility are critical sub-variables in determining the robustness of dynamic capacities, as they adequately improve increasing sales growth, survival, and sustenance of enterprise into the unforeseeable future, efficiency of enterprise, and competitive advantage of food and beverage manufacturing enterprises, respectively, particularly in this trying period that is evidenced with technological change and competition, among others.
\end{abstract}

Keywords: Dynamic capacities, Enterprise, Performance, SEM

\section{Highlights}

- It was revealed in the study that product innovation is the singular variable that can adequately improve increasing sales growth.

- Competitive intensity and technological turbulence are the dual variables that can adequately improve the survival and sustenance of enterprises into the unforeseeable future.

- Technological capability and competitive intensity are the dual variables that could improve the efficiency of enterprises.

- Strategic flexibility is the singular variable that could adequately improve the competitive advantage of food and beverage enterprises. 


\section{Introduction}

Over the years, business enterprises have been witnessing an unparalleled and exceptional degree of transformation, conversion, intense and forceful competition, and tumultuous environment globally. These transformations emanate as a result of market fragmentation, changing technology, dynamic management, the convergence of different business enterprises, supplier attitudes, changing customer demands, changing customer expectations, reduced lifecycle of product, etc. which have direct and indirect implications on business performance. According to Ahmad et al. (2014), business enterprises are encountering significant challenges because of the dynamic attributes of the business enterprise itself, the market, and environmental circumstances. In fact, in the current and widespread competition and challenging economic circumstances, a practicable, feasible, dynamic, and forceful enterprise network is vital to the economic improvement of a particular country (Zahra et al. 2006). In the same vein, Ahmad and Pirzada (2014) noted that enterprise networks are known to be the mechanism of growth and development which has significant roles in the establishment of laudable economic development. In the study of Hashim et al. (2018), it was revealed that majority of the countries often reply on the performance of enterprise networks for the growth and fortification of the economy. Zhu et al. (2013) and Dobbs and Hamilton (2007), noted that, however, enterprise networks are faced with many challenges and uncertainties in the competitive business environment and inauspicious circumstances in recent years. These have resulted in the challenges of superior and improved business performance.

According to Kayode (1989), enterprise networks are the heart of any economy. Its importance to the growth and survival of the economy cannot be overemphasized. Enterprise networks play a key and noticeable role in the economy of most countries. In the study, it was stated that the proceeds are oftentimes products offered to customers that result in profit making when pooled together by the owners of enterprise networks. Obisi (2013) in his study added that the enterprise networks all over the world would continue to be the engine of development and industrialization.

Nigeria is among the developing nations in the world that is competing in the intensity of the global market particularly in food and beverage manufacturing, and as a result of that, many business enterprises are springing up, especially those associated with large organizations. However, they need to maintain and catalyse the local market for economic stability and potency. It should be of importance to note that the survival of any enterprise into the unforeseeable future, its ability to extend tentacles, and its tendency of producing significant outputs is the goal of any enterprise in particular.

The ecosystem of enterprises in Nigeria is quite competitive and challenging, and the enterprise environment is neither perfect nor encouraging for small enterprises (Beugré, 2016). In fact, enterprises in Nigeria that seem to form a network are not doing it for expanding or growing the business dynamics, but to fulfil the mandate of the government by remitting some amounts. It is saddened to discover that most of the networks are politicized and influenced by corrupt individuals who will be the Lord of such networks. The aftermath of political influence has made some sets of individuals to enrich themselves with the money contributed by member networks for the advancement of the network. These scenarios have however reduced the trust of enterprise owners to forming a network. Nonetheless, Beugré opines that a small network of enterprises is necessary to have access to resources that will enhance the sustainable 
growth of various enterprises when in a difficult economic situation and highly competitive environment. Messeni Petruzzelli et al. (2018); Olusola et al (2010); Ahmad et al. (2014); Frankfort-Nachmias and Leon-Guerrero (2008) revealed that the hostile economic conditions give confidence to the enterprise networks for the purpose of surmounting the injurious business environment when realizing sustainable intensification of enterprises.

Hence, despite the inadequacies and inefficiencies in the operation of enterprise networks in Nigeria which have reduced the number of enterprise participants, the advantages of forming and belonging to an enterprise network were earlier identified. This study is therefore carried out within the Nigerian market by focusing on manufacturing enterprises most especially the food and beverage enterprises which are well-known for forceful competition for precincts, market share, and clients. The food and beverage manufacturing enterprises that are present and domesticated in the FMCG sector have encountered different challenges from the time when there was economic meltdown, which is in furtherance to powerful, ferocious, and increasing competition in the business enterprise and other macroeconomic indices such as decreasing oil prices, devaluing Naira currency, workers' salaries that are not paid; all these result in reduced spending (Industrial Report, 2016); Duranton, and Puga (2001).

At the global level, food and beverage manufacturing enterprises are known to be the bedrock and engine of a nation's development. According to Okere (2012), the food and beverage manufacturing enterprises are noted to be the main producers of foods and beverages that are consumed in Nigeria and the biggest sub-sector in the Nigerian manufacturing that were placed on the Nigerian Stock Exchange. Osundina (2014) further revealed that the enterprise is a dynamic and growing subsector of the Nigerian manufacturing industry which is witnessing unbendable and ferocious competition (KPMG, 2015).

According to Akpan and Ikon (2016), the frequent and persistent changing of Nigerian food and beverage manufacturing enterprises opens both opportunities and threats. In fact, the overall lapses of the food and beverage manufacturer are the pitiable operating environment in Nigeria and the high cost of production and operation. This has resulted in reduced output when compared with their counterparts in other developing nations. All these challenging issues have grave impacts on the performance of food and beverage manufacturing enterprises.

It is against this background that this study examined the impact of dynamic capacities on enterprise performance using food enterprises and beverage enterprises in Lagos, Nigeria, as case studies. It is pertinent to note that the interconnections between the attributes or constructs of dynamic capacities were tested on the attributes of enterprise performance. In this study, dynamic capacities were captured with respect to strategic decision-making capacity, product innovation capacity, strategic flexibility, competitive intensity, technological turbulence, and technological capability because of the dominancy of those variables in the manufacturing sector. The performance of enterprises was captured with sales growth, enterprise survival, enterprise, and competitive advantage.

\section{Literature review}

Dynamic capacities

The study was tending to determine the connection between dynamic capacities and enterprise performance. Dynamic capacities make organizations capable of such 
innovation by planning out suitable measures and finding out their effect on the accomplishment of the enterprise's goals (Sola et al. 2013); Wang and Ahmed, (2007). In the global world of competition, sustainable competitive advantage has been found to be of great importance and need in both the marketing and strategic management of a business. Other systems are being focused on other works conducted on the management and marketing of companies that tend to prove the worth of dynamic capacities within the enterprise (Ali et al. 2010). Propositions in regard to the use of dynamic capacities (DC) in enterprises with respect to environmental dynamism, product innovation, and enterprise performance are being developed continually towards the achievement of the enterprise's goals. (James and Zhou 2020); Akhtar and Mittal (2014); Teece (2007); Wang and Ahmed (2007).

DC facilitate an enterprise in its improved performances and its innovativeness in terms of enterprise networking, products, and advanced use of technology, as well as prepare an enterprise to survive in the ever-changing business environment. Based on the advantages of DC in the management of any organization, different propositions are developing towards the greater understanding of the need to integrate dynamic capacities in organizations for the betterment of performances (Zahra and Hayton 2008; Ayegba and Lin 2020).

Dynamic capacities have also been found to be a pertinent part in the product innovations and advanced uses of technology in different organizations. It can be realized that the focuses of dynamic capability on the changing needs of both the company as well as its customers and prepares an enterprise accordingly to face the challenges encountered due to the changing business environment. In other words, the concepts of DC help enterprises to adapt to the changes in the business environment. When dynamic capacities (DC) are involved in product technological and innovation changes, the enterprises also get assisted through the solutions available to technical problems and implementation of new processes and techniques (Thiel, 2010); Helfat et al (2009); Kumar et al (1998).

\section{Environment}

The greater need and importance of dynamic capacities arise owing to the constant changes that are prevailing in the business environment. Marketing capacities have been found to have a great positive influence on the economic performance of an organization in the global market. Kuo-Wei and Kai-Ping (2014) conducted a study on the significance of the dynamic capacities as observed in relation to company performances, enterprise networking, and accomplishments of objectives and goals; it may be drawn as a conclusion that DC have a major role to play in the organizational management where the managers and leaders are facilitated in their decision-making towards organizational success. DC can be observed as focusing on various aspects of an enterprise dealing with technological advances and product innovations, handling and facing challenges from the changing business environment as well as improving the performance of the enterprise as a whole.

The development of different propositions also reflects the increasing importance of dynamic capacities in organizations that managers are integrating into their strategic management practices all the more from before. While it can be realized that negative effects may occur on the performances and success of a company, this study reveals that the availability of dynamic capacities implies that an enterprise may be protected 
from the negative impacts through planned measures strategically intended to uncertainties and encounter challenges and yet perform to the utmost level and succeed in achieving organizational objectives and goals.

\section{Performance}

Earlier studies such as van Duren et al. (2003) noted that specific managerial factors were pointed by managers to influence enterprise profitability. Schumacher and Boland (2005); Pendell and Boland (2005) revealed that enterprise resources are dominant in explaining enterprise performance. Despite the helpfulness of these studies, they do not render the challenge impotent. Van Duren et al. adopted a case study procedure by conducting an interview on five enterprises. Small numbers of observations were revealed to limit the potency of the study when making generalizations to the food industry.

The study conducted by Pendell and Boland (2005) employed regression analysis to identify the return of investment on assets. Nonetheless, the sets of data were limited to secondary data without any primary data. Also, the study identified specific resources employed by the enterprises to realize better performance. Despite the fact that the similar studies being carried out were able to observe the pertinence of factors driving the efficiency of the enterprise, further analysis should be carried out to shed more light on the study. Further understanding can be exposed regarding the creation of competitive advantage, product innovation, and the performance of food enterprises and beverage enterprises in a highly competitive market as validated by recent studies conducted by Ayegba and Lin (2020). Furthermore, there are no earlier studies that have employed a structural equation model in the Nigerian food and beverage industry. Also, few studies have been able to achieve a direct connection between variables quantitatively, and be able to achieve the test of hypothesis.

Numerous studies have been carried out and have analyzed the antecedent variables that affect the nexus between dynamic capabilities and enterprise performance. Among are the studies of Vermeulen, De Jong, and O'shaughnessy (2005); Chang, Hughes, and Hotho (2011); Alegre and Chiva (2013); Thilenius et al (2016, but there are some gaps to be filled because of country-specific studies which open a prospect to observe the different variables that have a suspect of influencing this nexus. To embark on this, this study determines whether dynamic capabilities have an influence on enterprise performance.

\section{Competitiveness}

The studies carried out by Eisenhardt and Martins (2000); Helfat and Peteraf (2003); Winter (2003); Word (2009). focused more on the nexus between dynamic capabilities and competitive advantage of the enterprise networks.Gopalakrishnan, Kessler, and Scillitoe (2010) focused on competitive advantage and business performance. Keupp et al. (2012) focused on environmental factors and business performance. Gunday et al. (2011); Jegede et al. (2012); Hassan et al. (2013); AlShuaibi et al. (2016): James and Zhou (2020) focused on product innovation and enterprise networks in Turkey and noticeable. It is pertinent to note that the indices that were employed to capture dynamic capabilities and business performance may not be enough. 
Also, previous studies were limited to the attainment of business networks, network density, and network resources, and the existing body of academic and scientific literature may not have delved into the examination of the connection between dynamic capabilities of enterprise networks and enterprise performance. This proposed study aims to address and fill the lacuna.

\section{Theoretical background}

In the view of Sola et al. (2013), varieties of approaches have been adopted by the Nigerian government towards the improvement of efficiency, productivity, and output of the enterprise networks so as to improve economic growth and development. In the report of CBN (2003), the import substitution industrialization strategy took off and was adopted by the Nigerian nation during the First National Development Plan (19621968) with the aim of plunging the degree of finished products that were imported and the improvement of foreign exchange savings by producing locally some of the imported consumer goods. In the same vein, the Second National Development Plan period (1970-1974) signifies the consolidation of Nigeria's import substitution industrialization strategy during the era of oil boom. Sola et al. (2013) noted that during the wake of the world oil market that collapsed in the beginning of the 1980s, there was a rigorous/severe decline in the earnings accrued from oil exportation, which further led to the inability of the nation to uphold the emerged import-dependent industrial arrangement because of the enormous import bills.

In order to rescue the abovementioned economic challenges, a variety of policy measures in terms of context and contents were employed, which seems unsuccessful. Among the policy measures were the 1982 stabilization policy and the 1984 restrictive monetary policy and stringent exchange control. The collapse of the policy measures resulted in the acceptance and implementation of the 1986 Structural Adjustment Programme (SAP) (CBN 2003). In order to reduce the over-reliance of the nation's economy on crude oil which is the major foreign means of getting income, SAP was established by endorsing non-oil exports, most especially the enterprise networks. Sola et al. (2013) noted that the performance of the enterprise networks has been worrying the government in spite of a variety of efforts they exerted.

Accordingly, the Federal Government of Nigeria (FGN) begin with an economic programme referred to as NEEDS (National Economic Empowerment and Development Strategy) in 2003, this was to promote private sector participation in growth strategies (Essien and Bello, 2007). Though the policy document of NEEDS tends to be more entrepreneurial, the idea was basically useful for the large-scale industries. Additionally, it was identified in the policy document that there was "ineffective nexus between industry and the research institute/universities" and "lack of engineering and technical capacity to translate and decode research results into finished products and maintain existing machinery as well as low level of entrepreneurial capacity, technological support, and paucity of trained artisan skills". These are major impediments to the development of enterprise networks (Essien and Bello, 2007). The document was proffering a solution to the shortage of technological capabilities associated with enterprise networks which are needed to influence the level of efficiency.

The performance of enterprises in their business networks is quite affected by several factors such as reduced sales, high cost of production, reduced capital utilization, 
shortage of foreign exchange to procure the needed inputs, pitiable and unstable power supply, reduced quality of goods and services, and incessant taxation, among others (Adeoye and Elegunde 2012). Among other issues associated with enterprise networks are high import dependency, political instability, deceitful governance, and political bias with resource distribution, decentralization practices, high cost of funds, weak, defect, and unsound policies formulation and implementation, high level of fake and counterfeited goods that are imported, micro-economic instability, deformed business atmosphere, invisible governance, etc. According to Olamade et al. (2013); Coulson (2016), the penalties of these issues on the national economy include, among others, the loss of enterprises "pull effect" on other sectors of the economy, and the loss of chances to partake in the global economy when participating in the value chains at the international level.

In many of the enterprise networks, there is an understanding that the world's economy is passing through a period of colossal transformation alongside improbability that is full of uncertainties. In fact, incremental transformations are activated in many of the cost structure, supply chains, and business models of enterprises (Dobbs, 2012). One of the chief issues that are often encountered in enterprise networks is the dimension of creating value and achieving competitive advantage in the respective industry sector. These concepts of value creation and competitive advantage are germane to business strategy. The quest and reality of creating value and competitive advantage are at the basis of organizational performance, and hence, the indulgence of sources to the sustenance of value creation and competitive advantage is now a key and noticeable area and dimension of study when it comes to strategic management (Barney, 1991; Porter, 1991; Barney, J. B. (2001); Kumar et al (2002).

Global competition has revealed the level of technological changes and the dynamics of customer demand for superior quality products/services at reduced prices (Dirisu et al. 2013). As competitive advantage is becoming less valuable, the performance of $\mathrm{Ni}$ gerian enterprise networks is highly influenced as many networks are facing drastic and unexpected transformations, emanating from technological advancement, change in customer demand, new regulations, and diffusion of new practices (Wilden et al. 2007; Helfat et al. 2007; Rhema and Saeed, 2015; Akpan and Ikon 2016). It is obvious in the literature review and practices of strategic management that meagre control of resources and capabilities is insufficient to maintain competitive advantage.

The tumultuous nature of enterprise networks' environment results in a large number of new challenges which must be examined with the use of dynamic capabilities. Attention must be centred on the inimitable resources that may lose their inimitability in the dynamic environment. Consequently, uninterrupted organizational rejuvenation recommends only a valuable and effectual mechanism for competitive advantage by erecting dynamic capabilities. A number of values created and related to dynamic capabilities have become known in strategic management, such as product development, strategic decision-making, knowledge creation, product innovation capability, technological capability, top managers capability, alliance and acquisition, and strategic flexibility (Zhang 2007; Ibidunni et al. 2014; Oghojafor et al. 2014).

In order to sustain and thrive in the unendingly dynamic and changing environment, the enterprise networks must constantly develop new resources and capabilities that will deal with the new demands (Teece et al., 1997; Eisenhardt and Martins 2000; Rindova and Kotha, 2001). The dynamic enterprise network environment with its 
capricious fast-changing environments (internal and external) provides privileges for growth and development, and value/wealth creation wealth which often poses some level or form of threats to most networks (Obiwuru, Oluwalaye and Okwu, 2011). The view on dynamic capabilities has risen to deal with the rigorous issue militating against the sustainable competitive advantage in the dynamic environment (Teece, Pisano and Shuen, 1997; Eisenhardt and Martins 2000).

The formation, rations, and victuals of value created and competitive advantage are realized when enterprise networks are able to recognize new and further opportunities, resources, and capabilities that are in line with recognized opportunities and change (Teece, 2009). The dominant competitions have obligated several enterprise networks for new approaches to arrive at a competitive edge. What was previously referred to as strategies have been modified in the modern era (Chirico and Salvato 2008); Ziolkowska (2013). Dynamic capability, according to Rehman and Saeed (2015), is a mainstay for any organization to thrive in the present dynamic environment. Enterprises that are responsive in product innovation and capability to effectively coordinate and redeploy competencies from within and without would be able to improve business performance. Such enterprises will have the power to build, join together, and renew their competencies to acclimatize to the transforming market needs (Wong, 2013); Kohli and Jaworski (1990).

Enterprise networks place more emphasis on the aim of providing and securing competitive advantages by reaching sustainable business intensification (Seung 2014) and creating value. It is unfortunate that enterprise networks often face high-level and predominant collapse worldwide. Past literatures revealed that about $40 \%$ of enterprises often encounter collapse during the first 2 years of start-ups in different countries of the world (Hashim et al. 2018). In the same vein, scholars have emphatically argued that the rate of failure or collapse of small network enterprises is much higher in the developing countries than in the developed countries (Sherazi, Iqbal, Asif, Rehman and Shah, 2013).

Enterprise networks are strategic resources that are essential for permitting the growth of businesses in a dynamic and competitive business environment (Machirori and Fatoki 2013). The authors further state that enterprise networks consist of small business owners and other businesses to acquire and share information and resources. Enterprise networks according to Hedvall et al. (2019) and Guo et al. (2018) are set up to strengthen their dynamic capabilities in a competitive business environment. The survival of enterprises depends on the performance of enterprises which could be strengthening as a result of cordial networks that are associated with its economic growth (Rodrigo-Alarcón et al. 2018); Kohli et al (1993); Narver and Slater (1990).

In order to deal with the drastic transformations in market dynamics, technologies, and competition, top managers mostly rely on the strategic decision-making ability to deal with the changing external factors that could aid the survival of a transforming environment. Enterprise networks have been able to accomplish competitive advantage over time in the course of embracing technological innovation as a strategic drive to realizing competitive advantage and creating value (Oghojafor et al. 2014). In due course, enterprise owners and managers will make strategic decisions and engage in thoughts that are innovative so as to cope with the changing dynamics of the environment to realize the successfulness of enterprise networks (Ibidunni and Inelo 2015); Oktemgil and Greenley (1997). 
According to Dreyer and Gronhaug (2004), in order for enterprise networks in a fiercely competitive environment to operate effectively in an increasingly complex environment, growing demands from customers, changes in regulatory frameworks, and technological encroachment will catalyse strategic managers to be flexible in dealings, most especially in a complex contemporary business environment that requires short product life cycles, swift changing preferences and increasing demand of customers, technological progression, and others (Shimizu and Hitt 2004).

This study seeks to examine the impact of dynamic capacities on enterprise performance using food enterprises and beverage enterprises in Lagos, Nigeria, as case studies. It is pertinent to note that the interconnections between the attributes or constructs of dynamic capacities will be tested on the attributes of enterprise performance. The following sub-variables (strategic decision-making capacity, product innovation capacity, strategic flexibility, competitive intensity, technological turbulence, and technological capability) were employed to represent the variable of dynamic capacity. Also, the following sub-variables (sales growth, enterprise survival, enterprise efficiency, and competitive advantage) were employed to represent the variable of enterprise performance. It is believed that this approach is capable of giving more plausible results.

\section{Research Methodology}

Research, philosophy, approach, and strategy

This section critically elucidates the approaches that were adopted in realizing the aim of this research. This study will employ a quantitative approach that entails a form of survey research as a research design for the purpose of exploring the observable fact and presents a well robust explanation to the identified problems that the study seeks to address. The survey design and the quantitative nature are essential because the questionnaire is a closed-ended type.

\section{Philosophy}

The sample for this study was achieved based on the 14 companies that were listed in the Nigerian Stock Exchange (NSE) bulletin of 2014 as indigenous and multinational enterprises. Among the 14 companies, 6 companies were tagged as food and beverage enterprises, but 6 enterprises will be selected for this study because of the ease of getting information as earlier explained by Udemba (2015) and Akpan and Ikon (2016).

\section{Approach}

From previous studies of Akpan and Ikon (2016) and Udemba (2015), it was revealed that soliciting information from the other eight companies was difficult; hence, the use of a questionnaire instrument was adopted to collect the primary data. The questions comprise of a rating scale which ranges from $5=$ Very High to $1=$ Very Low. The usefulness of the data collection method was identified in the study of Shammot (2014) and Carlos and Miguel (2013). Obrimah (2014) stated that the data collection method in a study usually provides answers to the research questions. This study employed close-ended questions of Likert type five-point scale which was modified. The data collection exercise lasted for approximately three (3) months (October to December 2019). According to Zikmund (2003); Treece (1982), the various error allowances will be determined and the 
suitable one will be chosen based on the discretion of the researcher. The administration of the questionnaire was performed using the assistance of four research assistants who were postgraduate students at a State university in Lagos State (LASU). The research assistants received training prior to the administration of the questionnaires. The training focused on data collection procedures such as the purpose of the study, administration of questionnaires, and ethical issues. A cover letter was attached to the questionnaire to highlight the purpose of the study. Before participating in the survey, respondents were requested to read through the letter with the help of the research assistants. Confidentiality of all respondents was noted. Participation in the study was strictly on a voluntary basis, and respondents could withdraw at any time during the research without any fear of victimisation/discrimination. The resultant data were subjected to descriptive statistical analysis, f-statistics, correlation, and regression analysis.

\section{Strategy}

The chosen error allowance of 0.04 will be employed to establish the sample size as shown in the equation below:

The formulae for achieving sample size $\mathrm{n}=\frac{\mathrm{Z}^{2}}{4 \mathrm{E}^{2}}$

where

$\mathrm{n}=$ Sample size;

$\mathrm{Z}=\mathrm{Z}$ score for the confidence interval (2.05);

$\mathrm{E}=$ Error allowance (0.04)

When inserted into the formula, sample size will be 656.6406, and approximately 657. It is therefore key and noticeable that the questionnaire distribution will target six hundred and fifty-seven respondents who are middle and top managers in the six food and beverage manufacturing companies.

\section{Modelling}

Structural equation modelling (SEM) of partial least square (PLS) was adopted to determine the connection that exists between the variables. It is a multivariate statistical technique that is employed for modelling complex connections between directly and indirectly observed (latent) variables. It is a general framework which simultaneously solves the systems of linear equations and encompasses other techniques through the incorporation and integration of regression, factor analysis, path analysis, and latent growth curve modelling (Bollen 1989; Catherine et al. 2012). SEM is used to estimate a system of linear equations to test the fit of a hypothesized "causal" model.

The first step in SEM deals with the visualization of a "path diagram" or hypothesized model which is usually based on prior knowledge of established theories. In path diagrams, rectangles typically represent observed or directly measured variables, and circles or ovals typically represent unobserved or latent constructs which are defined by measured variables. Unidirectional arrows represent causal paths, where one variable influences another directly, and double-headed arrows represent correlations between variables. As shown in the studies of McDonald and Ho (2002) and Pearl (2000), the term "arc" was preferred than "causal path".

Figure 1 illustrates an example SEM model. The system of equations can be written as a number of separate equations or with a general matrix notation. 
SEMs comprises of two sub-models, they are:

1) The measurement model estimates connections between the observed variables, also referred to as indicator variables, and latent variables; this is the same framework used in factor analysis. In regression and other statistical theories, "indicator variable" implies a binary yes/no sort of variable. Here, as is customary for SEM, "indicator variable" refers to a variable that is directly associated with a latent variable such that differences in the values of the latent variable mirror differences in the value of the indicator (Bollen, 2001).

2) The structural model develops the connections between the latent variables. For clarity of presentation, the system of equations will be described. The measurement model consists of the following equations, using standard notation used by Bollen (1989):

$$
\begin{array}{ll}
\mathrm{x}_{1}=\lambda_{1} \zeta_{1}+\delta_{1} & \mathrm{y}_{1}=\lambda_{3} \eta_{1}+\varepsilon_{1} \\
\mathrm{x}_{2}=\lambda_{2} \zeta_{2}+\delta_{2} & \mathrm{y}_{2}=\lambda_{4} \eta_{1}+\varepsilon_{2} \\
\mathrm{x}_{3}=\lambda_{3} \zeta_{3}+\delta_{3} & \mathrm{y}_{3}=\lambda_{5} \eta_{1}+\varepsilon_{3}
\end{array}
$$

where the x's and y's are observed indicators for latent variables, ¿'s and n's are latent variables, the $\lambda$ 's are the factor loadings, and $\varepsilon$ 's and $\delta$ 's are the errors or disturbance terms. In general matrix notation, the measurement model is written as

$$
\begin{aligned}
& \mathbf{x}=\Lambda_{x} \zeta+\delta \\
& \mathbf{y}=\Lambda y \eta+\varepsilon
\end{aligned}
$$

From the path diagram, the arrows point to the x's and y's, so they are modelled as dependent variables. Also, the factor loadings for $\mathrm{x}_{1}$ and $\mathrm{y}_{1}$ can be set to 1 , which can be done for two reasons:

i. The model is identifiable; and

ii. The latent variable is on the same statistical scale as the observed variables.

Model identification for SEM can also be achieved in other ways, such as setting the variance for the latent variable to 1 . Generally, the indicator with factor loading set to 1 is chosen based on what the analyst deems the best descriptor of the latent construct,

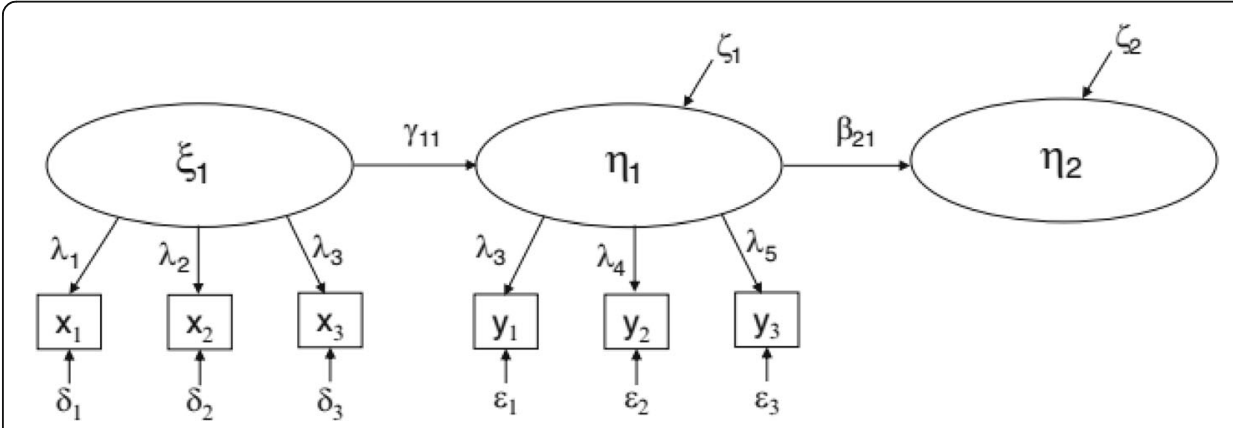

Fig. 1 Example of SEM model. Source: Catherine et al. (2012) 
but can be arbitrary. Finally, in respect to model specification for SEM, exogenous variables have been differentiated from endogenous variables. Exogenous variables have no directed arcs ending on them, while endogenous variables have at least 1 arc ending on them. The structural model consists of the following equations:

$$
\begin{aligned}
& \eta_{1}=\gamma_{11} \varepsilon_{1}+\zeta_{1} \\
& \eta_{2}=\beta_{21} \varepsilon_{2}+\zeta_{2}
\end{aligned}
$$

where the $\gamma$ and $\beta$ terms are factor loadings for the latent variables and $\zeta$ 's are error terms. Here, the causal connections between unobserved variables can be evaluated. In general, the structural model may be rewritten in matrix form as the following:

$$
\eta=\alpha+\mathbf{B} \eta+\Gamma \xi+\zeta
$$

where $\boldsymbol{\eta}$ is $m * 1$ vector of latent endogenous variables, $\boldsymbol{\xi}$ is an $n * 1$ vector of latent exogenous variables, $\boldsymbol{\alpha}$ is an $n * 1$ vector of intercept terms, $\mathbf{B}$ is an $m * m$ matrix of coefficients that give the influence of non each other, $\mathbf{r}$ is an $m^{*} n$ matrix of the coefficients of the effect of $\boldsymbol{\xi}$ on $\boldsymbol{\eta}$, and $\zeta$ is $m * 1$ vector of disturbances that contain the explained parts of the $\mathbf{\eta}$ 's. Though it may appear counterintuitive to regress on non itself, each variable in $\boldsymbol{\eta}_{\mathbf{i}}$ is influenced by other variables in $\boldsymbol{\eta}_{\mathbf{i}}$, so this represents connections between latent variables and not necessarily feedback loops. It was assumed that $\varepsilon, \delta$, and $\zeta$ are mutually uncorrelated.

\section{Regression}

Conventional regression approaches are robust to measurement errors in the outcome but not in the predictors. Also, univariate regression approaches cannot model the correlation between error terms for two different outcomes. SEM allows model measurement error for both the predictor and the outcome, and it allows a high degree of flexibility in modelling the correlation between the various error terms. In this study, the indicators were the constructs of dynamic capacities and enterprise performance; the analyst could model the correlation between one construct separately from another construct. Also, the SEM allows for the decomposition of effects if the direct and indirect effect of variables on the outcome is of interest.

For instance, the direct effect of $\eta_{1}$ on $\eta_{2}$ is estimated by $\beta_{21}$, and the indirect effect of $\zeta_{1}$ on $\eta_{2}$ is estimated by $\gamma_{11}$. Alternatively, one could model the direct effect of $\zeta_{1}$ on $\eta_{2}$ with the model depicted in Fig. 2, with the corresponding coefficient $\gamma_{12}$.

These models are estimated using the variance-covariance matrix of the data. Usually, maximum likelihood estimation fitting functions are used to fit the system of equations to the data, but this method requires that the data be normally distributed and the observations be independent. Variations that relax the assumption of multivariate normality have been developed, including the robust weighted least squares estimator (WLSM V), which allows for binary and categorical dependent variables (Muthe 'n, 1984). To assess the overall model fit, there are a number of fit statistics, including the root mean square error (RMSEA) and comparative fit index (CFI) (Bollen 1989), and for categorical data, the weighted root mean square residual (WRMR) is appropriate (Hancock and Mueller, 2006). $\mathrm{Hu}$ and Bentler (1999) categorize these fit statistics as 


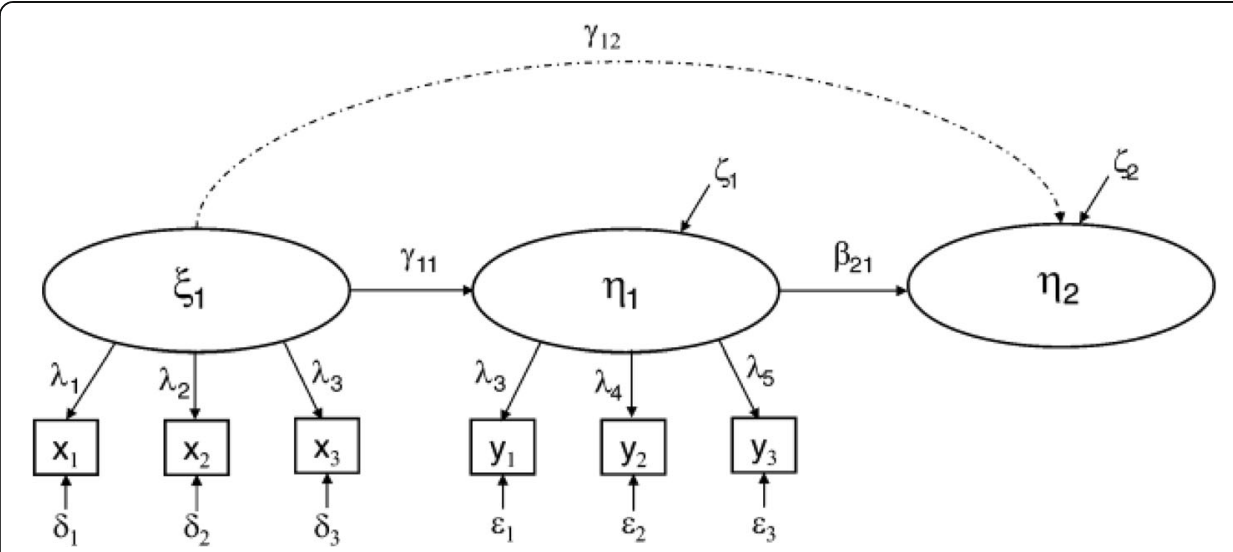

Fig. 2 Illustration of SEM diagram showing the addition of a direct effect in the model. Source: Catherine et al. (2012)

"comparative" or "absolute". One could also compare nested models, as is done with traditional regression models and segregation analysis models, using a likelihood ratio test (LRT) and non-nested models using Akaike's AIC; by contrast, the aforementioned fit statistics (RMSEA, CFI, WRMR, etc.) do not require the models being compared to be nested.

Fursova (2016) stated that researchers typically integrate the smart-PLS-SEM technique for developing theory in investigative research. The main applications of smartPLS-SEM are path analysis, confirmatory factor analysis, regression models, covariance structure models, second-order factor analysis, and correlation models as revealed by Hall et al. (2008). The approach of structural equation modelling (SEM) improves the analysis of the linear connection between the manifest variables and latent constructs.

The partial least squares (PLS-SEM) method is a multivariate statistical technique for evaluating a measurement model concurrently, such as the connection between the four constructs in this study and its indicators with a structural model to point out the connection between the constructs; this is evidenced in the study of Hair et al. (2013). In addition to the connection, it could also manifest obtainable parameter estimates to determine the connection between unobserved variables.

Typically, the SEM technique gives way for numerous associations to test and compute at once in the single proposed models with several associations instead of examining each connection individually. This present study will adopt the partial least squares (PLS-SEM) technique to scrutinize and analyze the collected data, as it will improve the evaluation of the conceptual model empirically. PLS-SEM, according to Vinzi et al. (2010) and Astrachan et al. (2014) is a path for modelling statistical techniques and a complex multivariate analysis for examining the connections between latent variables.

In the same vein, the PLS-SEM research approach is a flexible, superior, and robust technique to design or build a plausible statistical model (Ringle et al. 2009; Lowry and Gaskin 2014; Hair et al. 2017) and the PLS-SEM features improve the achievement of the stated objective. Peterson and Kim (2013) and Astrachan et al. (2014) made emphasis that a reliable and valid confirmatory factor analysis can be properly achieved with the use of PLS-SEM path modelling. 
PLS-SEM is a statistical tool that has been adopted in different fields including engineering and technology and social sciences (Ringle et al. 2009). The technique is well applicable for analysis that deals with non-normal data because of its assumed flexibility when concerned with the distribution and normality of variables (Lowry and Gaskin 2014). According to Lowry and Gaskin (2014), the PLS-SEM method improves the test of complex models that have multi-stage effects, for example mediating role and other complex models' variables connections. In line with the various evidences rooted in the body of scientific literatures, this study will adopt the partial least squares (PLS-SEM) technique for testing and examining the designed conceptual model and achieving the hypothetical statements.

By so doing, it will examine the connection between the constructs of dynamic capacities and enterprise performance, and the conforming constructs' indicators with a structural model. This study will incorporate the PLS-SEM for data screening and analysis and the underline assumptions will be taken critically in order to compute loadings, path coefficients, and weights; the study will also employ the bootstrapping method to determine the significance levels as evidenced in the study of Hair et al. (2013).

Reasons for adopting PLS-SEM are:

i. PLS can be applied to both small and large samples;

ii. It can be adopted in the situation whereby there is no theory or theoretical basis;

iii. It is applicable for both probability and non-probability sampling distribution;

iv. It allows for both reflective and formative latent variables;

v. It requires only the formation of indices or indicators;

The approach will be based on creating latent factors from the questionnaire based on an exploratory factor analysis. The resulting factors will then be evaluated in terms of their influence on the dependent variables in the model setup. There are four sets of equations to be included in the entire model, they are:

i. Measurement of equations: Equation 1 links the measurement indicators (survey items) to the latent factors;

ii. PLS equations: Equation 2 associates the latent factors with individuals' background characteristics;

iii. Structural equations: Equation 3 relates the explanatory and the mediator variables; and

iv. Structural equations: Equation 4 links the mediators to the dependent variables.

$$
\begin{aligned}
& I_{r n}=Z^{*}{ }_{l n} \alpha r+v_{r n} \text { and } v_{n} \sim\left(0, \Sigma_{v}\right) \text { for } r=1, \ldots, R \\
& Z^{*}{ }_{l n}=S_{l n} \beta_{l}+\omega_{l n} \text { and } \omega_{n} \sim\left(0, \Sigma_{\omega}\right) \text { for } l=1, \ldots, L \\
& Z^{*}{ }_{l}=Z_{i} \beta_{i}+\phi_{l} \text { and } \phi_{l} \sim\left(0, \Sigma_{\phi}\right) \text { for } l=1, \ldots, L, i=1, \ldots, \\
& Y_{\text {in }}=Z^{*}{ }_{l n} \beta_{z}+\xi_{\text {in }} \text { and } \xi_{n} \sim\left(0, \Sigma_{\xi}\right) \text { for } i=1, \ldots,
\end{aligned}
$$


where $I_{r n}$ is the value of an indicator $r$ of the latent construct $Z_{l n}^{\prime \prime}$ will be perceived by respondent $n, Z_{l n}^{*}$ will be the value of latent construct $l$ for respondent $n, S_{l n}$ will be the vector of $M$ respondents' observed individual characteristics, and $Y_{i n}$ will be the vector of enterprise performance levels. Error terms will be presented as elements $\omega_{l n}$, $v_{r n}, \xi_{\text {in }}$ of the vectors following a normal distribution with respective covariance matrix $\Sigma_{\omega}, \Sigma_{v}, \Sigma_{\xi}$, while parameters to be estimated are $\alpha_{r}, \beta_{l}, \beta_{i}$, and $\beta_{z}$. Considering $R$ indicators translates into writing $R$ measurement equations and estimating an $(R \times 1)$ vector $\alpha$ of parameters (i.e., one parameter is estimated for each equation), while considering $L$ latent constructs translates into writing $L$ structural equations and estimating an $(M \times L)$ matrix of $\beta$ parameters (i.e., $M$ parameters will be estimated for each equation).

The interconnection of dynamic capacities and enterprise performance is shown in Fig. 3 below. The independent variable is dynamic capacities and the dependent variable is enterprise performance. The dynamic capacities are represented with strategic decision-making, technological turbulence, strategic flexibility, technological capability, product innovation, and competitive intensity, while enterprise performance is represented with sales growth, enterprise survival, competitive advantage, and enterprise efficiency.

\section{Results and discussions}

In the study, dynamic capacity was captured with respect to strategic decision-making capacity, product innovation capacity, strategic flexibility, competitive intensity, technological turbulence, and technological capability. The performance of enterprises will be captured with sales growth, enterprise survival, enterprise efficiency, and competitive advantage.

PLS-SEM method is employed to estimate dynamic capacity on enterprise performance. SEM model is calibrated by using the Lisrel 8.70. The SEM models of various enterprises are adjusted based on the underlying principles of $\mathrm{T}$-value minimum and maximum. The indicators of six enterprises are shown in Table 1. According to the chi-squared test $\left(x^{2} / \mathrm{df}\right)$, the $x^{2}$ value is significant, where the lower the chi-square value, the lower the difference between the definite matrix and input matrix, and the realistic the goodness-of-fit test will be. It is pertinent to note that the goodness-of-fit

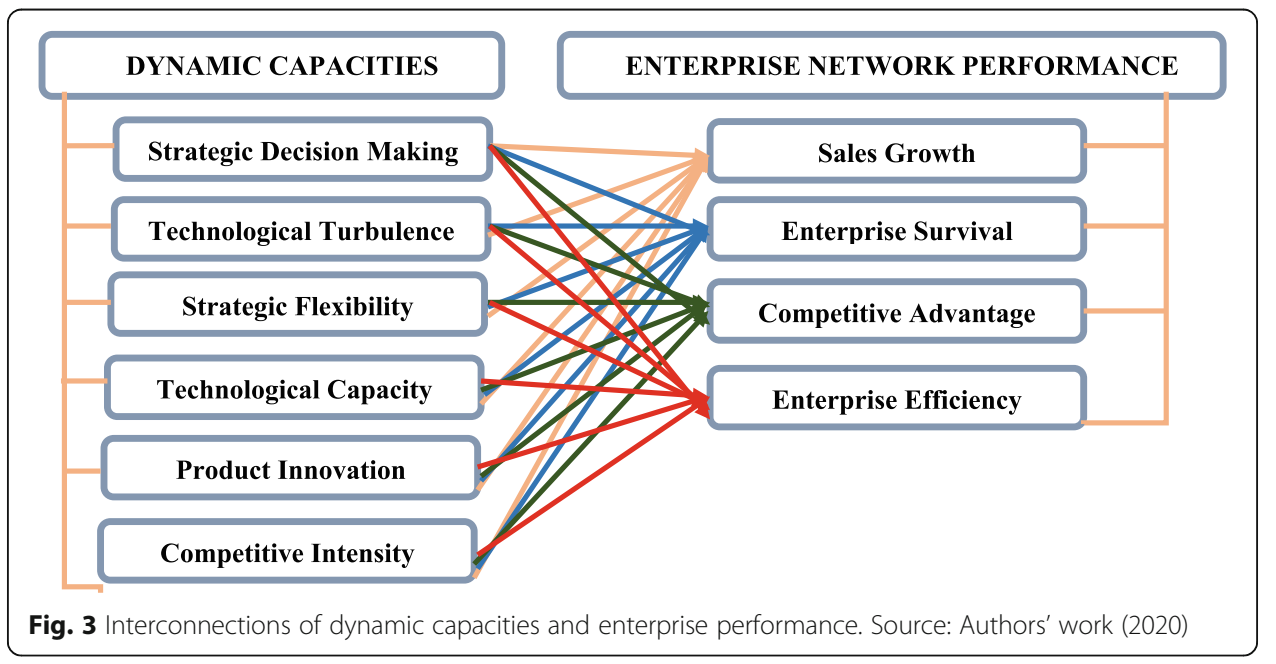


Table 1 Goodness-of-fit test

\begin{tabular}{lllllll}
\hline List of enterprises & $\mathbf{X} \mathbf{2} / \mathbf{d f}$ & GFI & IFI & CFI & RMR & RMSEA \\
\hline 1 & .332 & .72 & .92 & 1.00 & .047 & .049 \\
2 & .395 & .86 & .91 & 1.00 & .073 & .018 \\
3 & .346 & .78 & .92 & 1.00 & .015 & .036 \\
4 & .358 & .72 & .86 & .92 & .024 & .008 \\
5 & .294 & .80 & .91 & .91 & .017 & .014 \\
6 & .226 & .76 & .82 & 1.00 & .048 & .050 \\
\hline
\end{tabular}

Source: Lisrel 8.70 output (2020)

indexes (GFI) are satisfactory between 0.72 and 0.86 , the incremental fit indexes (IFI) are satisfactory between 0.82 and 0.92 , and the comparative fit indexes (CFI) are satisfactory between 0.91 and 1.00. These indicators are guided by a rule that they must not be more than 1.00, which gives a numerical evidence of perfect fitness. Hence, the goodness-of-fit test is said to be satisfactory from the holistic point of view.

Furthermore, the values of the root mean square residual indexes (RMR) range from 0.015 and 0.073 , and the root mean square error of approximation indexes (RMSERA) range from 0.008 and 0.050 . The values of these indicators are quite low and, can be said to be satisfactory.

From the path diagram to stress the inter-connectivity of dynamic capacities and enterprise performance shown in Fig. 3, the numerical analysis for decision is shown in Table 2 below. The connections between the four latent variables of enterprise performance and the six observed variables of dynamic capacities were revealed. In discussing the level of impact, each of the enterprise performance variables was used to measure each of the variables embedded in dynamic capacity.

The factors of dynamic capacities which are product innovation, strategic decisionmaking, technological capability, strategic flexibility, competitive intensity, and technological turbulence have a significant impact on enterprise performance (as captured by sales growth), the coefficients are $.850, .114, .052,-.041,-.097,-.094$, respectively, and the significant values are $.000, .003, .027, .081, .060, .080$ respectively. When examining the values obtained for coefficient and significant values, it was discovered that dynamic capacity of product innovation is the singular variable that can adequately improve increasing sales growth with a coefficient of $\mathbf{0 . 8 5 0}$ which greatly tend towards 1.00 and a significance of $\mathbf{0 . 0 0 0}$ which is less than the critical region of 0.05 .

Also, concerning the impact of dynamic capacities (product innovation, strategic decision-making, technological capability, strategic flexibility, competitive intensity, and technological turbulence) on enterprise performance (as captured by enterprise survival), the coefficients are $.002, .079,-.007, .032, .585, .347$, respectively, and the significant values are $.836, .000, .487, .002, .000, .000$ respectively. When examining the values obtained for coefficient and significant values, it was discovered that dynamic capacities of competitive intensity and technological turbulence are the singular variables that can adequately improve the survival of the enterprise or sustain the enterprise into the unforeseeable future with a coefficient of 0.585 and 0.347 respectively which tend towards 1.00 , and significant values of $\mathbf{0 . 0 0 0}$ and $\mathbf{0 . 0 0 0}$ respectively which is less than the critical region of 0.05 . 
Table 2 Path coefficient between the latent variables and observed variables

\begin{tabular}{|c|c|c|c|c|}
\hline Path relation & $\begin{array}{l}\text { Standardized } \\
\text { estimate }\end{array}$ & $\begin{array}{l}\text { Standard } \\
\text { error }\end{array}$ & $\begin{array}{l}\mathrm{T} \\
\text { statistics }\end{array}$ & $\mathbf{P}$ \\
\hline Sales growth > Product innovation & .850 & .023 & 36.565 & .000 \\
\hline Sales growth > Strategic decision-making & .114 & .038 & 2.953 & .003 \\
\hline Sales growth > Technological capability & .052 & .023 & 2.217 & .027 \\
\hline Sales growth $>$ Strategic flexibility & -.041 & .022 & -1.750 & .081 \\
\hline Sales growth > Competitive intensity & -.097 & .049 & -1.882 & .060 \\
\hline Sales growth $>$ Technological turbulence & -.094 & .054 & -1.754 & .080 \\
\hline Enterprise survival $>$ Product innovation & .002 & .011 & .208 & .836 \\
\hline Enterprise survival > Strategic decision-making & .079 & .017 & 4.525 & .000 \\
\hline Enterprise survival > Technological capability & -.007 & .011 & -.696 & .487 \\
\hline Enterprise survival > Strategic flexibility & .032 & .010 & 3.096 & .002 \\
\hline Enterprise survival > Competitive intensity & .585 & .022 & 25.215 & .000 \\
\hline Enterprise survival >Technological turbulence & .347 & .025 & 14.308 & .000 \\
\hline Enterprise efficiency > Product innovation & .030 & .049 & .741 & .459 \\
\hline Enterprise efficiency> Strategic decision-making & .121 & .082 & 1.789 & .074 \\
\hline Enterprise efficiency > Technological capability & .263 & .050 & 6.413 & .000 \\
\hline Enterprise efficiency $>$ Strategic flexibility & .142 & .048 & 3.494 & .001 \\
\hline Enterprise efficiency > Competitive intensity & .213 & .105 & 2.363 & .018 \\
\hline Enterprise efficiency > Technological turbulence & -.142 & .116 & -.1 .516 & .130 \\
\hline Competitive advantage $>$ Product innovation & -.035 & .023 & -.1 .583 & .114 \\
\hline $\begin{array}{l}\text { Competitive advantage }>\text { Strategic decision- } \\
\text { making }\end{array}$ & -.029 & .038 & -.809 & .419 \\
\hline Competitive advantage $>$ Technological capability & -.026 & .023 & -.1 .178 & .239 \\
\hline Competitive advantage $>$ Strategic flexibility & .870 & .022 & 39.893 & .000 \\
\hline Competitive advantage $>$ Competitive intensity & .048 & .048 & .993 & .321 \\
\hline $\begin{array}{l}\text { Competitive advantage }>\text { Technological } \\
\text { turbulence }\end{array}$ & -.030 & .053 & -.603 & .547 \\
\hline
\end{tabular}

Source: Lisrel 8.70 output (2020)

In addition, concerning the impact of dynamic capacities (product innovation, strategic decision-making, technological capability, strategic flexibility, competitive intensity, and technological turbulence) on enterprise performance (as captured by enterprise efficiency), the coefficients are $.030, .121, .263, .142, .213,-.142$ respectively and the significant values are $.459, .074, .000, .001, .018, .130$ respectively. When examining the values obtained for coefficient and significant values, it was discovered that dynamic capacities of Technological capability and Competitive intensity are the singular variables that could improve the efficiency of enterprise with a coefficient of $\mathbf{0 . 2 6 3}$ and $\mathbf{0 . 2 1 3}$ respectively which slightly tend towards 1.00 , and significant values of $\mathbf{0 . 0 0 0}$ and $\mathbf{0 . 0 1 8}$ respectively which is less than the critical region of 0.05 .

Concerning the impact of dynamic capacities (product innovation, strategic decisionmaking, technological capability, strategic flexibility, competitive intensity, and technological turbulence) on enterprise performance (as captured by enterprise competitive advantage), the coefficients are $-.035,-.029,-.026, .870, .048,-.030$ respectively and the significant values of $.114, .419, .239, .000, .321, .547$, respectively. When examining the values obtained for coefficient and significant values, it was discovered that dynamic capacity of strategic flexibility is the singular variable that could adequately improve the 
competitive advantage of an enterprise over other enterprises with a coefficient of $\mathbf{0 . 8 7 0}$ which greatly tend towards 1.00 , and a significant value of $\mathbf{0 . 0 0 0}$ which is less than the critical region of 0.05 . The path coefficient table is shown in Table 2.

This section presents the discussion of the findings that emanated from the data analysis. The Lisrel 8.70 version was adopted for analysing SEM. From the findings, it was revealed that product innovation is the singular variable that can adequately improve increasing sales growth. Competitive intensity and technological turbulence are the dual variables that can adequately improve the survival and sustenance of enterprises into the unforeseeable future. Technological capability and Competitive intensity are the dual variables that could improve the efficiency of enterprises. Strategic flexibility is the singular variable that could adequately improve the competitive advantage of food and beverage enterprises.

This study corroborates the findings of Rajee (2005) which found that product innovation is the basis for competitive advantage; Wang and Ahmed (2004) which reveals that innovation is a prerequisite for the survival and success of an organization; and Jegede et al. (2012) which found that innovation is an influencing factor of competiveness in Nigeria's oil and gas servicing firms.

Furthermore, the study discovered that innovation of products improves firms' sales, revenue and profitability, and this is mediated on research and development, and training. This is agreed in the study of Mohd et al. (2013) which found that internal motivation for employees, employees' promotion, and retaining talented employees have a significant influence on sales growth.

Also, it was affirmed in the study that sales growth could be determined within the framework and trend of industry as well as local, national, and regional economies. The finding also corroborates the findings of Ibidunni et al. (2014) which found a significant nexus between product innovation and the survival of SMEs.

The study agrees with the findings of Aw and Batra (1998), which found a strong positive connection between technological capability and firm efficiency of the manufacturing industry in Taiwan based on the total expenditure of R\&D and on-the-job training. Subsequently, the study of Acha (2005) which substitutes technological capability with $R \& D$ expenditure, publications, and patents found that there is a positive connection between the attributes of technological capability and a firm's operational performance. In southwest Nigeria, Olabisi, Ilori and Egbetokun (2013) conducted a study on technological capabilities in the automobile mechanic industry. Their study found that the investment capability of automobile mechanics was weak; meanwhile, marketing capability was revealed to be strong especially the customers and spare part supplies.

This study agrees with the findings of Obembe et al. (2014) which confirm that firms with superior technological capability are likely to generate innovations and become extremely competitive. This is implying that technological capacities have a key and noticeable effect when determining the performance of enterprises. Also, Grewal and Tansuhaj (2001) and Dobni and Luffman (2003) revealed that strategic flexibility is a driver of enterprise performance which improves the competitive advantage over business players in the industry.

\section{Conclusion}

This study examined the impact of dynamic capacities on the performance of food and beverage enterprises in Lagos, Nigeria. The following sub-variables (strategic decision- 
making capacity, product innovation capacity, strategic flexibility, competitive intensity, technological turbulence, and technological capability) were employed to represent the variable of dynamic capacity. Also, the following sub-variables (sales growth, enterprise survival, enterprise efficiency, and competitive advantage) were employed to represent the variable of enterprise performance. Primary data was used to achieve descriptive and inferential statistics, and the statistics is estimated by the PLS-SEM method which was calibrated on Lisrel 8.70 software.

\section{Theoretical implications}

The study found that product innovation is the singular variable that can adequately improve increasing sales growth. Competitive intensity and technological turbulence are the dual variables that can adequately improve the survival and sustenance of enterprises into the unforeseeable future. Technological capability and competitive intensity are the dual variables that could improve the efficiency of enterprises. Strategic flexibility is the singular variable that could adequately improve the competitive advantage of food and beverage enterprises.

\section{Managerial implications}

From the study, product innovation, competitive intensity and technological turbulence, technological capability and competitive intensity, and strategic flexibility are critical sub-variables in determining the robustness of dynamic capacities, as they adequately improve increasing sales growth, survival, and sustenance of enterprise into the unforeseeable future, efficiency of enterprise, and competitive advantage of food and beverage manufacturing enterprises respectively, particularly in this trying period that is evidenced with technological change, competition, among others.

When making managerial decisions pertaining to increasing sales growth, dynamic capacity of product innovation should be focused on. Also, decisions on enterprise survival into the unforeseeable future, dynamic capacities of competitive intensity, and technological turbulence should be prioritized. Finally, regarding the decisions on competitive advantage, dynamic capacity of strategic flexibility should be the focus.

\section{Research limitations}

This study is limited to the impact of dynamic capacities on the performance of food and beverage enterprises in Lagos, Nigeria. The following sub-variables (strategic decision-making capacity, product innovation capacity, strategic flexibility, competitive intensity, technological turbulence, and technological capability) were employed to represent the variable of dynamic capacity. Also, the following sub-variables (sales growth, enterprise survival, enterprise efficiency, and competitive advantage) were employed to represent the variable of enterprise performance.

Since this study is limited to ten variables, and six food and beverage enterprises across Lagos, Nigeria, future studies may consider more variables that will be more robust for factor analysis. Also, samples may be drawn from enterprises across West African States (ECOWAS). Comparative analysis with other countries may be conducted by the researcher in future studies. It may also be conducted by researchers that want to imitate the study. 


\section{Abbreviations}

SEM: Structural equation modelling; ECOWAS: Economics Community of West African States; PLS: Partial least square; NSE: Nigerian Stock Exchange; WLSMV: Weighted least squares estimator; FGN: Federal Government of Nigeria; NEED S: National Economic Empowerment and Development Strategy; LRT: likelihood ratio test; SDM: Strategic decisionmaking; TC: Technological capability; SF: Strategic flexibility; Cl: Competitive intensity; TT: Technological turbulence; RMSERA: Root mean square error of approximation indexes; LASU: Lagos State University

\section{Acknowledgements}

This article was proof read by Associate Professor Anthony Onoja of University of Port-Harcourt ,River State of Nigeria, Sir, we sincerely appreciate your intellectual and technical contributions offered.

\section{Declarations}

\section{Authors' contributions}

All authors have modified and approved the submitted manuscript drafted.

\section{Authors' information}

Dr. James Onuche Ayegba received his B.S. degree in 2006 from Ahmadu Bello University, Zaria Nigeria, He earned his MBA degree in June 2015 from Jiangsu University, Zhenjiang, Jiangsu Province, 212013 China, Having Enrolled for his doctoral degree in Autumn of 2015, He had recently defended his dissertation on 28th May, 2021 hosted by the School of Management, Jiangsu University and was awarded a PhD degree in Management Science and Engineering.His research interests include; strategic planning and management in small and medium-size enterprises, game theory, Chaos theory, knowledge of large scale enterprise, human resource management particularly in food and beverages enterprises, Finally his dissertation was centered on Enterprise Networks in SMEs of which this manuscript is pivoted on majorly, it's findings had contributed significantly to the field of strategy planning and management.

Zhou Lu Lin is a Professor at the School of Management, Jiangsu University. His research interest includes small and medium-scale entrepreneurship (SMEs), Health Economics and Public Health management and health insurance Scheme management.

Ayegba Jiangsu He received his B.S. degree in 2006 from the Ahmadu Bello University, Zaria

Emmanuel Onu Ayegba is an engineer and a Strategist at the Marketing head office of The Nigerian National Petroleum Corporations, Abuja Nigeria. He is based at the Department of Marketing and Business Section. He received his B.S. degree in 2003 from Abubakar Tafawa Balewa University Bauchi, Nigeria. He received his M.E. 2019 from Ahmadu Bello University, Zaria Nigeria

Peace Maina Ayegba is currently an admission candidate for PDG Education candidate at Kaduna State University, Nigeria. She hopes to base at the Department of Education, Kaduna State University. She received her B.S., Accounting in 2017 from the Department of Accounting, Nasarawa State University, Keffi, Nigeria. Her research interest includes knowledge management in large, medium-scale firms, and strategic management of third-world economies, financial and marketing accounting, and human resources management.

Zhang Xin Jie is a lecturer at Jiangsu University, China. She is based at the School of Management, Jiangsu University. She received her B.S. (Statistics) degree in 2007 from Jiangsu University. She received her M.S. in 2011 from the Jiangsu University and Ph.D. in 2015 from Jiangsu University. Her research interest includes strategy management, senior health management, and health insurance management.

\section{Funding}

Not Applicable.

\section{Availability of data and materials}

The datasets generated during and/or analysed during the current study are available from the corresponding author on reasonable request.

\section{Competing interests}

The authors have no competing interests.

\section{Author details}

${ }^{1}$ School of Management Science and Engineering, Jiangsu University, Jiangsu 212013, China. ${ }^{2}$ Department of Business Strategy and Planning, Nigerian National Petroleum Corporation, Abuja 900271, Nigeria. ${ }^{3}$ Department of Accounting, Nasarawa State University, Keffi 960169, Nigeria.

Received: 27 April 2020 Accepted: 7 June 2021

Published online: 27 December 2021

\section{References}

Acha, V., Gann, D. M., \& Salter, A. J. (2005). Episodic innovation: R\&D strategies for project-based environments. Industry \& Innovation, 12(2), 255-281.

Adeoye, A. O., \& Elegunde, A. F. (2012). Impact of external business environment on organizational performance in the Food and Beverage Industry in Nigeria. British Journal of Arts and Social Sciences, 6(2), 194-201.

Ahmad, N., Othman, S. N., \& Lazim, H. M. (2014). A review of technological capability and performance connection in manufacturing companies. 2014 International Symposium on Technology Management and emerging technologies (ISTM ET 2014). 
Ahmad, Y., \& Pirzada, D. S. (2014). Using analytic hierarchy process for exploring prioritization of functional strategies in auto parts manufacturing SMEs of Pakistan. SAGE Open, 4(4), 2158244014553560.

Akhtar, M., \& Mittal, R. K. (2014). Strategic Flexibility, Information System Flexibility and Enterprise Performance Management. In Organisational Flexibility and Competitiveness (pp. 41-51). Springer, New Delhi.

Akpan, P. L., Ikon, M., Chukwunonye, O., \& Nneka, M. I. (2016). Economic Environment and Performance of Food and Beverage Sub-Sector of a Developing Economy: Nigeria. International Journal of Recent Research in Commerce Economics and Management (IJRRCEM), 3(3), 85-90.

Akpan, P. L., \& Ikon, C. M. (2016). Economic environment and performance of food and beverage manufacturing enterprises sub-sector of a developing economy: Nigeria. InternationalJournal of Recent Research in Commerce Economics and Management (IJRRCEM), 3(3), 85-90.

Alegre, J., \& Chiva, R. (2013). Linking entrepreneurial orientation and firm performance: The role of organizational learning capability and innovation performance. Journal of Small Business Management, 51(4), 491-507. https://doi.org/10.1111/jsbm.12005.

Ali, S. L. D., Peters, H., \& Lettice, F. (2010). Market based organisational learning, dynamic, and substantive capacities: An integrative framework. Journal of Strategic Marketing, 18(5), 363-377. https://doi.org/10.1080/0965254X.2010.497846.

AlShuaibi, K., Zain, M., \& Kassim, N. (2016). Performance indicators for quality, innovation, and competitiveness: A survey on the Saudi manufacturing sector. International Business Research, 9(2), 99-113. https://doi.org/10.5539/ibr.v9n2p99.

Astrachan, C. B., Patel, V. K., \& Wanzenried, G. (2014). A Comparative Study of CB- SEM and PLS-SEM for Theory Development in Family Firm Research. Journal of Family Business Strategy, 5(1), 116-128. https://doi.org/10.1016/j.jfbs.2013.12.002.

Aw, B. W., \& Batra, G. (1998). Technological capability and firm efficiency in Taiwan (China). The World Bank Economic Review, 12(1), 59-79. https://doi.org/10.1093/wber/12.1.59.

Ayegba, J. O., \& Lin, Z. L. (2020). Empirical review of enterprise networks on company performance. International Entrepreneurship Review / Przedsiębiorczość Międzynarodowa, 3(1). https://doi.org/10.15678/PM.2017.0302.02.

Baller, S., Dutta, S., \& Lanvin, B. (2016). Global information technology report 2016. Geneva: Ouranos.

Barney, J. (1991). Firm resources and sustained competitive advantage. Journal of management, 17(1), 99-120.

Barney, J. B. (2001). Is resource-based "view" a useful perspective for strategic management research? Yes. Academy of Management Review, 26(1), 41-56.

Barney, J. B., \& Clark, D. N. (2007). Resource-based theory: Creating economic rents andcompetitive advantage. Oxford: Oxford University Press.

Beugré, C. (2016). Social entrepreneurship: Managing the creation of social value. Taylor \& Francis.

Bollen, K. (1989). Structural Equations with Latent Variables. New York: John Wiley \& Sons. https://doi.org/10.1002/97811 18619179.

Bollen, N. P., \& Busse, J. A. (2001). On the timing ability of mutual fund managers. The Journal of Finance, 56(3), 1075-1094.

Catherine, M. S., Nathan, J. M., \& Nora, L. N. (2012). Structural Equation Modelling, Chapter 27. In R. C. Elston et al. (Eds.), Statistical human genetics: methods and protocols, methods in molecular biology, (vol. 850, pp. 495-512). https://doi.org/1 0.1007/978-1-61779-555-8_2.

CBN (2003). Contemporary economic policy issues in Nigeria. Abuja, Nigeria: CBN Publication.

Chang, Y. Y., Hughes, M., \& Hotho, S. (2011). Internal and external antecedents of SMEs' innovation ambidexterity outcomes. Management Decision.

Chirico, F., \& Salvato, C. (2008). Knowledge integration and dynamic organizational adaptation in family firms. Family Business Review, 21(2), 169-181. https://doi.org/10.1111/j.1741-6248.2008.00117.x.

Coulson, A. B. (2016). KPMG's True Value methodology. Sustainability Accounting, Management and Policy Journal.

Dirisu, J. I., Iyiola, O., \& Ibidunni, O. S. (2013). Product differentiation: A tool of competitive advantage and optimal organizational performance (A Study of Unilever Nigeria PIc). European Scientific Journal, 9(34), 258-282.

Dobbs, M., \& Hamilton, R. T. (2007). Small business growth: Recent evidence and new directions. International Journal of Entrepreneurial Behaviourand Research, 13(5), 296-322. https://doi.org/10.1108/13552550710780885.

Dobbs, R., Madgavkar, A., Barton, D., Labaye, E., Manyika, J., Roxburgh, C., ... \& Madhav, S. (2012). The world at work: Jobs, pay, and skills for 3.5 billion people (Vol. 28). Washington: McKinsey Global Institute.

Dobni, C. B., \& Luffman, G. (2003). Research notes and commentaries: Determining the scope and impact of market orientation profiles on strategy implementation and performance. Strategic Management Journal, 24(6), 577-585. https:// doi.org/10.1002/smj.322.

Dreyer, B., \& Grønhaug, K. (2004). Uncertainty, flexibility, and sustained competitive advantage. Journal of business research, 57(5), 484-494.

Duranton, G., \& Puga, D. (2001). Nursery cities: Urban diversity, process innovation, and the life cycle of products. American Economic Review, 91(5), 1454-1477. https://doi.org/10.1257/aer.91.5.1454.

Eisenhardt, K. M., \& Martins, J. A. (2000). Dynamic capabilities: What are they? StrategicManagement Journal, 21, 1105-1121.

Essien, E. A., \& Bello, Y. A. (2007). Technical efficiency of small and medium scale industries (SMI) in Nigeria: evidence from nation-wide sample survey. Journal studia universitatis babesbolyai negotia, 4(2), 39-69.

Finney, S. J., DiStefano, C., Hancock, G. R., \& Mueller, R. O. (2006). Structural equation modeling: A second course. LAPInformation Age Publishing Inc, United States, Chapter Non-normal and categorical data in structural equation modelling, 269-314.

Frankfort-Nachmias, C., \& Leon-Guerrero, A. (2008). Student Resources. SAGE, 8, 8-293.

Fursova, J. (2016). The business of community development and the right to the city: Reflections on the neoliberalization processes in urban community development. Community Development Journal, 53, 119-135.

Gopalakrishnan, S., Kessler, E. H., \& Scillitoe, J. L. (2010). Navigating the innovation landscape: Past research, present practice, and future trends. Organization Management Journal, 7(4), 262-277.

Grewal, R., \& Tansuhaj, P. (2001). Building organizational capabilities for managing economic crisis: The role of market orientation and strategic flexibility. Journal of Marketing, 65(2), 67-80. https://doi.org/10.1509/jmkg.65.2.67.18259.

Gunday, G., Ulusoy, G., Kilic, K., \& Alpkan, L. (2011). Effects of innovation types on enterprise performance. International Journal of Production Economics, 133(2), 662-676. https://doi.org/10.1016/.jijpe.2011.05.014.

Guo, H., Xu, H., Tang, C., Liu-Thompkins, Y., Guo, Z., \& Dong, B. (2018). Comparing the impact of different marketing capabilities: Empirical evidence from B2B firms in China. Journal of Business Research, 93, 79-89. https://doi.org/10.1016/j. jbusres.2018.04.010. 
Hair, J. F., Hult, G. T. M., Ringle, C., \& Sarstedt, M. (2013). A Primer on Partial Least Squares Structural Equation Modeling(PLSSEM). Thousand Oaks: SAGE Publications.

Hair, J. F., Sarstedt, M., Ringle, C. M., \& Gudergan, S. P. (2017). Advanced issues in partial least squares structural equation modelling. Thousand Oaks: SAGE Publications.

Hall, P. C. M., Müller, D. K., \& Saarinen, P. J. (2008). Nordic tourism: issues and cases. Bristol: Channel View Publications. https:// doi.org/10.21832/9781845410957.

Hashim, N. A. B., Raza, S., \& Minai, M. S. (2018). Connection between entrepreneurial competencies and small firm performance: Are dynamic capabilities the missing link? Academy of Strategic Management Journal, 17, 1-10.

Hassan, M. U., Shaukat, S., Nawaz, M. S., \& Naz, S. (2013). Effects of innovation types on enterprise performance: An empirical study on Pakistan's manufacturing sector. PakistanJournal of Commerce and Social Sciences, 7(2), 243-262.

Hedvall, K., Jagstedt, S., \& Dubois, A. (2019). Solutions in business networks: Implications of an inter-organizational perspective. Journal of Business Research, in press, 104, 411-421. https://doi.org/10.1016/j.jbusres.2019.02.035.

Helfat, C. E., Finkelstein, S., Mitchell, W., Peteraf, M., Singh, H., \& Winter, D. (2007). Dynamic capabilities: Understanding strategic change in organizations. UK: Blackwell.

Helfat, C. E., \& Peteraf, M. A. (2003). The dynamic resource-based view: Capability lifecycles. Strategic Management Journal, 24(10), 997-1010. https://doi.org/10.1002/smj.332.

Helfat, C. E., \& Peteraf, M. A. (2009). Understanding dynamic capabilities: Progress along a developmental path. Strategic Organization, 7(1), 91-102. https://doi.org/10.1177/1476127008100133.

Hu, L. T., \& Bentler, P. M. (1999). Cutoff criteria for fit indexes in covariance structure analysis: Conventional criteria versus new alternatives. Structural equation modeling: a multidisciplinary journal, 6(1), 1-55.

Ibidunni, O. S., \& Inelo, F. (2015). Market oriented strategic flexibility and market performance of the furniture industry in Southwest Nigeria under fierce competitive environment. Sky Journal of Business Administration and Management, 3(1), 8-16.

Ibidunni, O. S., Iyiola, O., \& Ibidunni, A. S. (2014). Product innovation, a survival strategy for small and medium enterprises in Nigeria. European Scientific Journal, 10(1), 194-209.

Janjić, I., \& Popović, V. (2015, October). Effective implementation of eLearning-Romanian language and literature classes for university students in Serbia. In Virtual learninig-virtual reality, The 10th International Conference on Virtual Learning-ICVL (pp. 447-452).

James, O. A., \& Zhou, L. L. (2020). A Review on Dynamic Capacities in Strategic Management. Przedsiębiorczość Międzynarodowa, 3(1). https://doi.org/10.15678/PM.2017.0302.02.

Jegede, O. O., Ilori, M. O., Sonibare, J. A., Oluwale, B. A., \& Siyanbola, W. O. (2012). Factors influencing innovation and competitiveness in the service sector in Nigeria: A sub-sectoral approach. Management, 2(3), 69-79.

Kaya, I. (2016). The mandatory social and environmental reporting: Evidence from France. Procedia-Social and Behavioral Sciences, 229, 206-213.

Kayode, M. O. (1989). Nigeria since independence: The first 25 years. Ibadan: Heinemann Books Ltd.

Keupp, M. M., Palmié, M., \& Gassmann, O. (2012). The strategic management of innovation: A systematic review and paths for future research. International journal of management reviews, 14(4), 367-390.

Kohli, A. K., \& Jaworski, B. J. (1990). Market orientation: The construct, research propositions, and managerial implications, Journal of Marketing, 54(2), 1-18. https://doi.org/10.1177/002224299005400201.

Kohli, A. K., Jaworski, B. J., \& Kumar, A. (1993). MARKOR: A measure of market orientation. Journal of Marketing Research, 30(4), 467-477. https://doi.org/10.1177/002224379303000406.

KPMG (2014). Fast-Moving Consumer Goods in Africa. Cayman Islands: A Sector Report of KMPG Africa Limited.

Kumar, S., Jantsch, A., Soininen, J. P., Forsell, M., Millberg, M., Oberg, J. Hemani, A. (2002, April). A network on chip architecture and design methodology. In Proceedings IEEE Computer Society Annual Symposium on VLSI. New Paradigms for VLSI Systems Design. ISVLSI 2002 (pp. 117-124). IEEE.

Kumar, M. M., Srinivas, A., Suryanarayana, S. V., Kumar, G. S., \& Bhimasankaram, T. (1998). An experimental setup for dynamic measurement of magnetoelectric effect. Bulletin of Materials Science, 21(3), 251-255.

Kumar, K., Subramanian, R., \& Strandholm, K. (2002). Market orientation and performance: Does organizational strategy matter? Journal of Applied Business Research, 18(1), 1-37.

Kumar, K., Subramanian, R., \& Yauger, C. (1998). Examining the market orientation-performance connection: A context-specific study. Journal of Management, 24(2), 201-233. https://doi.org/10.1177/014920639802400204.

Lin, K. W., \& Huang, K. P. (2014). Moral judgment and ethical leadership in Chinese management: the role of Confucianism and collectivism. Quality \& Quantity, 48(1), 37-47.

Lin, Z. L., Ayegba, J. O., Onu, E., James, P. M., \& Jie, Z. X. (2020). Impact Of Dynamic Capacities On Enterprise Performance: Case Studies Of Food Enterprises And Beverage Enterprises In Lagos, Nigeria.

Lowry, P. B., \& Gaskin, J. (2014). Partial Least Squares (PLS) Structural equation modeling (SEM) for Building and Testing Behavioral Causal Theory: When to choose it and how to use it. IEEE Transportation Professional Communication, 57(2), 123-146. https://doi.org/10.1109/TPC.2014.2312452.

Machirori, T., \& Fatoki, O. (2013). The impact of firm and entrepreneur's characteristics on networking by SMEs in South Africa. Journal of Economics, 4(2), 113-120. https://doi.org/10.1080/09765239.2013.11884971.

McDonald, R. P., \& Ho, M. H. (2002). Principles and practice in reporting structural equation analyses. Psychological Methods, 7(1), 64-82. https://doi.org/10.1037/1082-989X.7.1.64.

Messeni Petruzzelli, A., Ardito, L., \& Savino, T. (2018). Maturity of knowledge inputs and innovation value: The moderating effect of firm age and size. Journal of Business Research, 86, 190-201. https://doi.org/10.1016/j.jbusres.2018.02.009.

Mohd, F., Mohd, S., \& Hoshino, Y. (2013). Sales growth, profitability and performance: empirical study of Japenese ICT industries with three Asean countries. Interdisciplinary Journal of Contemporary Research in Business, 4(11), 138-156.

Muthén, B. (1984). A general structural equation model with dichotomous, ordered categorical, and continuous latent variable indicators. Psychometrika, 49(1), 115-132.

Narver, J. C., \& Slater, S. F. (1990). The effect of a market orientation on business profitability. Journal of Marketing, 54(4), 2035. https://doi.org/10.1177/002224299005400403.

Obembe, J. J., Ojo, O. J., \& Ilori, M. O. (2014). Effects of technological capabilities, innovations and clustering on the performance of firms in the Nigerian furniture industry. International Journal of Management Technology, 2(2), 19-28. 
Obisi, C., Samuel, R., \& Elegbede Sikirulahi, T. (2013). ORGANIZATION EFFECTIVENESS: BEYOND WORKERS'RIGHTS AND MANAGEMENT PREROGATIVES. International Journal of Asian Social Science, 3(1), 204-215.

Obrimah, O. A. (2014). Private Sector Profitability and Depreciation Pressure within Managed Floating Exchange Rate Regimes: Evidence from Nigeria. Available at SSRN 2475527.

Obiwuru, T. C., Oluwalaye, B. O., \& Okwu, A. T. (2011). External and Internal environments of Business in Nigeria. International Bulletin of Business Administration, (12).

Oghojafor, B. E. A., Kuye, O. L., Ogunkoya, O. A., \& Shobayo, P. B. (2014). Competitive strategies, technological capabilities and organizational performance: Evidence from Nigerian manufacturing industry. Arabian Journal of Business and Management Review(Nigerian Chapter), 11-22.

Okere, R. I. (2012). Nigeria's food, beverage industry riding above the storm. Guidian Retrieved on December 3, 2014 from http://www.ngrguadiannews.com.

Oktemgil, \& Greenley (1997). Consequences of high and low adaptive capability in UK companies. European Journal of Marketing, 31(7), 445-466.

Oladele, O. I., Akinsorotan, A. O., \& Ajadi, A. A. (2010). Knowledge and utilization of job enrichment techniques among agricultural extension managers in Botswana and Nigeria. The Journal of International Social Research, 3(12), 327-334.

Olamade, O. O., Oyebisi, T. O., \& Egbetokun, S. O. (2013). Manufacturing business environment in Nigeria strategic characteristics and implications. Advances inManagement and Applied Economics, 3(6), 53-65.

Olusola, A. A., Oladele, A. S., \& Abosede, D. O. (2010, October). Analysis of KDD'99 intrusion detection dataset for selection of relevance features. In Proceedings of the world congress on engineering and computer science (Vol. 1, pp. 20-22). WCECS.

Osundina, J. A. (2014). Working capital management and profitability: Evidence from quoted food and beverage manufacturing enterprises manufacturing firms in Nigeria. Research Journal of Finance andAccounting, 5(4), 101-107.

Pearl, J. (2000). Causality: Models, Reasoning, and Inference. New York, New York: Cambridge University Press.

Pendell, D., \& Boland, M. (2005). Persistence of profitability in family-owned food businesses. Providence, RI: Paper presented at 2005 annual meetings of the American Agricultural Economics Association.

Pérez-Miguel, C., Miguel-Alonso, J., \& Mendiburu, A. (2013). High throughput computing over peer-to-peer networks. Future Generation Computer Systems, 29(1), 352-360.

Peterson, R., \& Kim, Y. (2013). On the Connection between Coefficient Alpha and Composite Reliability. Journal of AppliedPsychology, 98, 194

Porter, M. E. (1991). Towards a dynamic theory of strategy. Strategic management journal, 12(S2), 95-117

Rahrami, H. (1992). The emerging flexible organization: Perspectives from Silicon Valley. California Management Review, 34(4), 33-52. https://doi.org/10.2307/41166702.

Rajee, F. S. (2005). Sustaining product Innovation in the new economy: The case of Lever Brother Nigeria Limited. Journal of Sales and Marketing, 4(16), 21134.

Rindova, V. P., \& Kotha, S. (2001). Continuous "morphing": Competing through dynamic capabilities, form, and function. Academy of management journal, 44(6), 1263-1280.

Ringle, C. M., Sinkovics, R. R., \& Henseler, J. (2009). The use of partial least squares path modelling in international marketing. In New Challenges to International Marketing, (pp. 277-319). West Yorkshire: Emerald Group Publishing Limited.

Rodrigo-Alarcón, J., García-Villaverde, P. M., Ruiz-Ortega, M. J., \& Parra-Requena, G. (2018). From social capital to entrepreneurial orientation: The mediating role of dynamic capabilities. European Management Journal, 36(2), 195-209. https://doi.org/10.1016/j.emj.2017.02.006.

Schumacher, S., \& Boland, M. (2005). The effects of industry and firm resources on profitability in the food economy. Agribusiness, 21(1), 97-108. https://doi.org/10.1002/agr.20033.

Seung, K. A. (2014). A study on the business ecosystem of German SMEs and its implications for Korean SMEs: Focusing on the hidden champion enterprises in Germany. Korean Journal of Economics Management, 32, 69-95.

Shammot, M. M. (2014). The role of human resources management practices represented by employee's recruitment and training and motivating inrealization competitive advantage. The Retail and Marketing Review, 10(2), 18-37.

Sherazi, S. K., Iqbal, M. Z., Asif, M., Rehman, K., \& Shah, S. H. (2013). Obstacles to small and medium enterprises in Pakistan. Principal component analysis approach. Middle-East journal of scientific research, 13(10), 1325-1334.

Shimizu, K., \& Hitt, M. A. (2004). Strategic flexibility: Organizational preparedness to reverse ineffective strategic decisions. Academy of Management Executive, 18(4), 44-59.

Shylesh, S., Schuenemann, V., \& Thiel, W. R. (2010). Magnetically separable nanocatalysts: bridges between homogeneous and heterogeneouscatalysis. Angewandte Chemie International Edition, 49(20), 3428-3459.

Sola, O., Obamuyi, T. M., Adekunjo, F. O., \& Ogunleye, E. O. (2013). Manufacturing performance in Nigeria: Implications for sustainable development. Asian Economic andFinancial Review, 3(9), 1195-1213.

Teece, D. J. (2007). Explicating dynamic capabilities: The nature and microfoundations of sustainable enterprise performance. Strategic Management Journal, 28(13), 1319-1350. https://doi.org/10.1002/smj.640.

Thilenius, P., Pahlberg, C., \& Havila, V. (2016). Extending the business network approach: New territories, new technologies, new terms. London: Palgrave Macmillan. https://doi.org/10.1057/978-1-137-53765-2.

Treece, E. W., \& Treece, J. W. (1982). Elements of research in nursing, (3rd ed., ). St. Louis: Mosby

Teece, D. J. (2007). Explicating dynamic capabilities: the nature and microfoundations of (sustainable) enterprise performance. Strategic management journal, 28(13), 1319-1350.

Teece, D. J. (2009). Dynamic capabilities and strategic management: Organizing for innovation and growth. Oxford University Press on Demand.

Udemba, F. S. (2015). Understanding the food, beverages and tobacco operating environment, (p. 17). Manufacturing Association of Nigeria News.

van Duren, E., Sparling, D., Turvey, C., \& Lake, L. (2003). An assessment of the strategies and strengths of medium-sized food processors. Agribusiness: An International Journal, 19(1), 115-132.

Vermeulen, P. A., De Jong, J. P. \& O'shaughnessy, K. C. (2005). Identifying key determinants for new product introductions and firm performance in small service firms. The Service Industries Journal, 25(5), 625-640.

Vinzi, V. E., Chin, W. W., Henseler, J., \& Wang, H. (2010). Handbook of partial least squares: Concepts, methods and applications, (1st ed., pp. 1-798). Berlin/Heidelberg, Germany: Springer. https://doi.org/10.1007/978-3-540-32827-8. 
Wang, C. L., \& Ahmed, P. K. (2004). The development and validation of the organisational innovativeness construct using confirmatory factor analysis. European journal of innovation management.

Wang, C. L., \& Ahmed, P. K. (2007). Dynamic capabilities: A review and research agenda. International Journal of Management Reviews, 9(1), 31-51. https://doi.org/10.1111/j.1468-2370.2007.00201.X.

Wang, Y., Lo, H., Zhang, Q., \& Xue, Y. (2006). How technological capability influences business performance: An integrated framework based on the contingency approach. Journal of Technology Management in China, 1(1), 27-52. https://doi. org/10.1108/17468770610642740.

Wilden, R., Gudergan, S. P., \& Lings, I. (2007). Dynamic capabilities and organizational performance. Ph.D Thesis, University of Technology, Sydney. Management, 49(2), 114-136.

Winter, S. (2003). Understanding dynamic capabilities. Strategic Management Journal, 24(10), 991-995. https://doi.org/10.1002/ smj.318.

Wong, K. K. K. (2013). Partial least squares structural equation modeling (PLS-SEM) techniques using SmartPLS. Marketing Bulletin, 24(1), 1-32.

Word, J. (2009). Business network transformation: strategies to reconfigure your business connections for competitive advantage, (p. 279). Hoboken: Wiley.

Zahra, S. A., \& Hayton, J. C. (2008). The effect of international venturing on firm performance: The moderating influence of absorptive capability. Journal of Business Venturing, 23(2), 195-220. https://doi.org/10.1016/j.jbusvent.2007.01.001.

Zahra, S. A., Saprienza, H. J., \& Davidson, P. (2006). Entrepreneurship and dynamic capabilities: A review, model and research agenda. Journal of Management Studies, 43(4), 917-955. https://doi.org/10.1111/j.1467-6486.2006.00616.x.

Zhang, M. J. (2007). IS support for top managers' dynamic capabilities, environmental dynamism, and firm performance: An empirical investigation. Journal of Business and Management, 13(1), 57-77.

Zhu, Q., Cordeiro, J., \& Sarkis, J. (2013). Institutional pressures, dynamic capabilities and environmental management systems: Investigating the ISO 9000 Environmental management system implementation linkage. Journal of Environmental Management, 114, 232-242. https://doi.org/10.1016/j.jenvman.2012.10.006

Zikmund, W. G. (2003). Exploring Marketing Research, (8th ed., ). Cincinnati: Thompson Learning/Southwestern.

Ziolkowska, J. R. (2013). Evaluating sustainability of biofuels feedstocks: A multi-objective framework for supporting decision making. Biomass and Bioenergy, 59, 425-440.

Ziokowska, M. (2013). Relational resources management as source of company's innovativeness and competitive advantage. Journal of Economic, Business and Management, 2(3), 202-208.

\section{Publisher's Note}

Springer Nature remains neutral with regard to jurisdictional claims in published maps and institutional affiliations.

\section{Submit your manuscript to a SpringerOpen ${ }^{\circ}$ journal and benefit from:}

- Convenient online submission

- Rigorous peer review

- Open access: articles freely available online

- High visibility within the field

- Retaining the copyright to your article

Submit your next manuscript at $\boldsymbol{\nabla}$ springeropen.com 